\title{
THE UNITY OF PERSONALITY IDEAS OF KANT, HEGEL, NITSHE, VAINTSVAIG, PLATO, DAVID THE INVICIBLE AND GAREGIN I, BENEDICT XVI
}

\author{
"I accept the truth regardless who has issued it." Pifagor \\ "I do not agree with your opinion, but I am ready to devote \\ my life for your liberty to express it." Volter
}

\begin{abstract}
In the present paper theories of creative personality are considered, developed by great philosophers, social psychologists, humanists, and also by representatives of religious confessions. On base of known triad of Hegel about subjective, objective and absolute spirit is done relative gradation of personality, which is containing in each man: 'Empiric', 'Social' and 'Super empiric' man or simply creative subject in all aspects. All this is related also to gradation of whole peoples and states. On this base it is shown complete coincidence of, on first sight contrary theories of personality. It is shown, that often first and second types of man demonstratively break laws of mentioned categories, pursuing in their actions, unnecessary for nobody momentary benefits and 'victories'. As it was mentioned by Pope Benedict, the rescue of the Mankind is in the rapprochement and in community of all religions in general for all these doctrines, the creation of an image of the pure high strong personality. There aren't any differences between these doctrines.

The analysis of many contemporary problems in psychology and ethics of individuals and nations in terms of priority common to all approaches to relationships of modern conditions of the individual and society, of all countries and peoples are given.
\end{abstract}

Keywords: creative personality, Superempiric personality, spiritual perfection, Civilization, mankind, human being.

In the present paper theories of creative personality are considered, developed by great philosophers, social psychologists, humanists, and also by representatives of religious confessions. On base of known triad of Hegel about subjective, objective and absolute spirit is done relative gradation of personality, which is containing in each man: 'Empiric', 'Social' and 'Super empiric' man or simply creative subject in all aspects. All this is related also to gradation of whole peoples and states. On this base it is shown complete coinci- dence of, on first sight contraries, theories of Kant and Nitshe about personality. It is postulated the presence of three unconditional categories: $\mathrm{Na}$ ture, Civilization, History, whose laws nobody can break with impunity, the corresponding examples are given. It is shown, that often first and second types of man demonstratively break laws of mentioned categories, pursuing in their actions, unnecessary for nobody momentary benefits and 'victories'. It is shown also unity of view on personality of mentioned thinkers and those of the supreme 
patriarch of All Armenians Garegin I. It is shown full correspondence of ideas of Plato, developed by representative of his school David Invincible, with theories of Kant, Hegel, Nitshe. The great German philosopher Hegel in his work 'Phenomenology of Spirit' wrote that the World Idea in its other being, i.e. in mankind, accomplish the process of selfknowledge. It is well known how it was occurred actually, namely all motions of human history have passed in infinite destructive wars, in violation by the states and their rulers of elementary human rights. Especially brightly it appeared in the XX century, when for two well-known totalitarian regimes neither human rights nor even human lives in fact means nothing. Nowadays, after wreckage of mentioned 'Empire of harm' the mankind somehow came to the conclusion that the main value in the world is the human personality and human rights. In 1990 was published the book of the well-known Canadian social psychologist Paul Vaintsvaig 'Ten precepts for the creative personality" translated into Russian. In its foreword Soviet psychologist V.S.Ageev had written pathetically about actuality of aspirations of the image of valuable, creative in everything personality, especially in questions of interrelation between people. The Biblical character of the name of the book adjusts on the highest hopes in reception of precise recommendations in that important issue, and the author justifies them. In our paper (Bagdoev, Manukyan 1999 ) we, certainly independently, came to the same conclusions as P. Vaintsvaig had. Both he and we put liberty and creation in the first place in the ethics of the creative personality of the present and especially of the future, and appeal to refuse in the vital acts from the purposes of achievement of momentary petty benefits and victories and certainly from aspiration for the domination above people. In his book instead of our term 'Superempiric personality' or simply subject of creation in all, Vaintsvaig used the concept the 'Personality Power'. Certainly 'power' is considered to be not the household concept of physical power, not even the power of character of aspiration to superiority over surrounding people, but self-perfection of personality, self-knowledge and spiritual perfection. Non momentary successes and victories over surrounding people can be compared to this Personality Power. About the same it is spoken and in (Daniel, 1990) where it is directly told, that attitudes in community are frequently characterized by tactical reasons and momentary benefits, and they do not correspond to those high principles that should be peculiar to attitudes of creative persons who have been proclaimed by the great thinkers, particularly by F.Nitshe. By the way, specified situation in attitudes of people to what it opposed with an image of the raised strong personality that is identical (Daniel, 1990) to correctly understood term of the superman entered by it, takes place also in the modern human society consisting from creative persons, but in practical interests cooperating at a lower level (Bagdoev, Manukyan, 1999). It is necessary to note, that in introduction to the book (Daniel, 1990) of the French scientist D. Galevi, it is spoken about the urgency of the question of creation of original philosophy of the person. And in (Otto, 1910) it is directly spoken about the basic value and the purpose of the world development: 'What is the center of apperception?', 'It is the personality'. Very close to ethical principles are ideas of Christian morals. They were stated in the interview by the Catholicons of All Armenians Garegin I to the famous Italian writer D.Guajta (Guayta, 1990), where he said that the human happiness is not in his well-being and momentary benefits, successes and victories, but in self knowledge and development of the spiritual life. It is deeply stated by Garegin I, that people who are not burdened with families, whose typical representative he was, even unwillingly, began to think in cosmic scale and live with the interests of the Universe. Now we can return to the problem of synthesis of ethical studies of great thinkers of the last and the present, and also additions to them being formulated by the first author of (Bagdoev , 
Manukyan, 1999) in 1968, his ethical problems. Kant in his ethical recommendations said: "One must relate to man not only as to means but also as to aim". F.Nitshe in his book "So it is said by Zaratustra” wrote: “I teach you about 'Superman'. The man is that what must be overcome". "In a man it is great that he is a bridge, not an aim." "Let your will tell you 'Superman' must become the meaning of the Earth". The impression is that theories about personality of Kant and Nitshe are opposite. Nevertheless it is said that all personality theories of all great philosophers and thinkers almost do not differ from each other, since they have the same aim-creation of image of perfect personality. We shall show that truly interpreted above mentioned declarations of Kant and Nitshe coincide with each other. First of all let us remember known, typical far Hegel's philosophy triad about 3 kinds of man's spirit, or simply of man, -subjective spirit, objective spirit, absolute spirit. Naturally it is considered, that as the first type of man one must understand "empiric man" with all its dignities and defects, and, it is fixed, that justly it is overcome by the second type of man, namely by social man or simply collective, which has his own truth and morals and makes to obey to them the 'empirical' person and to serve together with the all others to the general, other very useful, goals posed by the collective. But also this type of man cannot be the aim of the all development of nature and mankind since each collective has its own "truth" and aims and that brings to collisions of between then and even to wars. Therefore social man also often must be overcome by 'Superempiric' personality, which can be believed, as it was said, as subject of creation in all. Neither Kant nor Nitshe had carried out that gradation; therefore their statements at first sight are opposite. However, it is easy to understand, and it is agreed with interpretation of Nitshe's philosophy, given in (Daniel, 1990), that by saying 'man' he meant just 'empiric man' which certainly must overcome his defects and vices, and by saying 'Superman' one must understand
'Superempiric personality' or simply just object of creation in all. The same is Kant's statement which due to height of his philosophy, certainly by saying 'man' to whom one must relate as to the aim, meant 'Superempiric man'. By the way, both Kant and Dostoevsky believed in primary imperfection, certainly in 'empiric man' and the same does Christianity in understanding of 'fall of man'. Namely, to the such type of man in Kant's declaration one must relate as to means. By Nitshe that man is a bridge, of course, for passage to 'superman'. Thus, using Hegel's triad about human spirit, we could reconcile and even join Kant's and Nitshe's statements about personality. And what about synthesis of Ethic studies of their personality theories, it was already said and will be said more in future. By the way the first attempt of synthesis of ethic theories and the presence of the 'sixth sense' of great Russian writers and thinkers and of the greatest Armenian poet and writer of the XX century was done by west Armenian writer Eduard Hovhanisyan in his book "Dostoevsky, Tolstoy, Sevak", published in Venice in 1977. The mentioned imperfection of 'empiric man' and 'public man' first was mentioned by Nitshe, whose phrase is recently often quoted in public papers is the following: "No any great idea, at least in its initial stage avoided distortion and misinterpretation, having passed through mankind". To the same conclusion we came independently, and that is why. Indeed, how many people were killed and burnt in the name of celebration of religious dogmas? Did Christ or Mohammed in their sacred books claim it? How many people were killed in the name of, appeared illusive 'victory' of light ideas of communism? Did Nitshe in his appeals on overcoming the 'empirical person' in our terminology claim to create gas chambers? About these distortions of Nitshes ideas by nazi were spoken both in (Daniel, 1990) and in the book of Czech expert on ethics Egnst. Certainly, utopian theories could avoid these distortions. The mentioned book (Guayta, 1990) also contained the statement of Garegin I that though 
the real carriers of creative activity are men, the carriers of the spiritual beginning. In interrelations between themselves and confession are women. This, at first sight, the paradoxical conclusion become clear, as Garegin I said, when we consider that men mainly were busy with making career and in interrelation between each other and surrounding, according our terminology at the highest level of 'public man', they act no more then on the level of momentary benefits and victories. By the way, we think, that as a compass for 'Superempiric personality' it is necessary to consider the presence of already mentioned triad of categories, laws of which cannot be broken with impunity.

The Nature, the Civilization, the History.

There are also other known concepts, to what everyone worships, but anyhow, they either contain instructions, or through them are expressed. Certainly, laws of Nature sometimes are broken in the important question of continuation of life, but as a rule, there are extenuating circumstances and finally the repentance of the marked person before himself and others takes place that certainly softens and usually eliminates the punishment. The majority of not strong-willed people simply are rescued by the Civilization, but also for all the others it remains the only way of self-expression and activity, without it they would be simply strong cave people. Nowadays it is well known and consequently that those even bullish figures, who, even sometimes, break its laws, showing not deserved, unjust attitude to the other people, as a rule sooner or later one estimates adequately. We are going to bring a well-known example about infringement of laws of History and immediate punishment. In 1973 under the initiative of another except M.Gorbachev, the Herrostrat-like laureate of the Nobel prize of the world, that he received when he had lost the shameful war for the USA in Vietnam, the State Secretary of the USA G.Kissinger and a well-known American company, had occurred a fascist military coup d'état in Chile. Israel, which wasn't asked about it, was the first who recognized that fascist junta, while flown into a rage from blood of citizens military clique applied inhuman tortures towards harmless captives, simply showing 'a blood bath' and disgracing not only themselves but also the all Chilean people. As far as we know, during our epoch, representatives of any other nations haven't shown such senseless sadism towards the fellow citizens. On the next day of the mentioned 'recognition', Arabs broke the 'unapproachable' Barley Line, and so the domination of Israel in the Near East was ended.

There are lots of other examples when somebody digs a ditch for the others, he himself gets into it. And one can ask where the mankind is. Certainly the mankind, to be exact, its best representatives, has created the Civilization and its main norms are well-known. But as it was already said that almost all, without exception, people in the past and the present, operating in their professional activities on the level of creative 'Superempirical' personality, as a rule in the interrelation among themselves act on the level of 'empirical', and in the best case, of the 'public' person, namely open conjuncture and generally speaking, of absolutely useless for them momentary benefits. And all these maybe are 'inevitable' and 'natural' but have no connection with the demands of the Civilization. Moreover, it concerns to the mutual relations between nations. In that sense the mankind in name of the state and separate leaders representing it at all levels had to deserve confidence of their citizens-creative or 'Superempirical' personalities. Its estimation of their creative actions and their positions among other people and nations almost never are at above-stated 'Superempirical' level. Easier being expressed, we may quote the Russian poet Yevtushenko, "Justice is a train that is always late". One must recognize that mentioned reasoning in the occasion of necessity, as possible, to act with the demands of the Civilization which, certainly, nobody can refute look a little bit grandiloquently and pretentiously in comparison with the simple humorous saying of 
'Great Combinatory' from the book of If and Petrov. "I would like to smash into your face but Zarathustra didn't allow."

By the way there is another quotation in the same book from the Bible. The matter is that in (Ajvazyan, 2006) devoted to the interpretation of historical and moral Bible truths, it is written that the great Jewish nation already for that feat which it has made by the creation of the Bible, is worth genuflection. It is difficult to add anything to that panegyric. However, also great Larosh Fuko had said: "Great people had great defects." So even on that great nation there should be corresponding compromises. It isn't a question of household defects that are often primitively and unreasonably attributed to Jews. In close contact the majority of the Jews known to us, are an example of wisdom, modesty and goodwill with sense of humor towards themselves and the surroundings. As to the compromises, certainly, it is well known on the highest level of power both in politics and in science. The great compromises consist with the presence at political leaders of Jews of two morals and estimations: in angry condemnation of the Holocaust and in full indifference, and even denying, of its forerunners, and even it is possible to tell confidently, of original cause, of non-recognition of the genocide of the Armenians in 1915. About this original cause once spoke the Frenzied Fuhrer in his appeals to the German soldiers: "Kill. Kill. Kill. Who remembers now the mass murders of Armenians?" Besides as writes in his book S. Ajvazyan, in his times the confessors of Israel-T.Herzl and Vainsman had addressed to the bloodthirsty sultan Hamid with suggestion; " Help us to create the state of Israel and we 'Il help you to solve the Armenian question." Close to our previous sayings there are in Ajvor Beison's book "The factor of Zionism"/2001/. Not standing on other examples let us bring only recommendation of the same ancient Yews from Bible, which is containing also in book of If and Petrov: "Sim the prayer is doing, Kham the wheat is sowing, Jafet the power is hawing». As it is seen the ancient Jews themselves conned to Yews of all times the Zole of creators of spiritual and mental values, the subjects of creation, but, on no account, not rulers over people, which never should not bring to them laurels. Of course, there are lots of exceptions, too. The most vivid one for us was A. Linkoln, who perhaps excepting of J.Kennedy and F.Roosevelt the only president of the USA, operating according our terminology, at a level of "Superempirical" person and was its typical example. By the way, in our activities we also, as possible try to be only the subject of creativity and we do not aspire to any official social standing, i.e. simply to authority, in this case being straight lines, even not consanguinity, successors to Sim.

By the way, the modern civilization and science mainly are carried by Jews. The great German mathematician and philosopher Leibnitz was named 'genius of compromise' as he tried in his philosophy to reconcile and approach Christian churches, and also religious morals and morals of the personality, based on the intellect. As one can see we are straight followers of Leibnitz in our aspiration for synthesis. He had met another great philosopher Spinoza and found out that they are antipodes in the question of moral. Both admit the spiritual origin, but Leibnitz, later Kant and Dostoevski, distinguished the presence of good and evil in that origin, appealed towards the bright ideal of the personality itself, as we do. Spinoza considers that in spiritual origin there were no gradation and simply one might adapt for it and for the surrounding reality. It is like very much Bantam's utility ethics of right understanding of interests. From our observation, mainly in scientific environment, we may confidently note that the civilized mankind, as it was mentioned, on the level of 'public' personality, including relations between scientists, and states, estimations of creative personalities, follow not the ethics of Leibnitz, Kant and Dostoevsky, maybe considering it more intelligent whim, but the rational and stiff ethics of Spinoza. But as it was already mentioned, these abso- 
lutely different morals of the 'public' man, i.e. collectives, countries, confessions will bring the mankind to the unknown. So, propagated by as the morals of 'Superempiric' personality or only creative not only in their own profession but also as it is more important, in relations towards themselves and surroundings, or that is the same, towards spirit, are, maybe, the only mean to unite people all over the world, and as we consider, the salvation of the mankind from itself. In detail, we'll speak about it in our next article: "The Universe of Spinoza and the Universe of Leibnitz." (2007, N 10).

We'll note that Garegin I supported rapprochement of all Christian churches (Guayta, 1990)

As it has been told earlier, there is much common in doctrines of great thinkers, which at first sight expresses differently, but at definition to their main aim -creating of an image strong and elevated creative person -spoke the same. It is possible to approve confidently the presence of also full accord of these doctrines with the ones of all Christian churches whose purpose is the same'spirituality' in human being, with appeals to act on that high, by our terminology 'Superempirical', level. It is possible to go further, and it was made by Pope Benedict XVI during his visit to Turkey. The pope had declared that the rescue of the Mankind is in the rapprochement, and, we may add, in community of all religions: Christianity, Moslem, Judaism, Confucianism, Buddhaism, in general for all these doctrines, the creation of an image of the pure high strong personality. There aren't any differences between these doctrines, as we know.

With regard to the aforesaid it is possible to apply Mao Tsze Donne's famous saying, 'Let blossom all the roses'. That can be carried both to unification of all churches and confessions and to mutual relations of scientists. By the way in present time in capital of Kazakhstan Astana already from 2006 there are organized conferences on union of all world religious confessions concepts to find the common aim for all peoples and confessions as primary value, which is in full correspondence with conceptions of this paper. Another matter is, that individualities of religions, nations and separate people, philosophical doctrines about personality, will certainly keep, but the main thing that unites them, that is to put on the top of the corner the person who is creative in all, anyhow should become the aim of all personalities and people. There is no other way for mankind at all. To say the truth, in present that basic position is known very much, the only question is; how much every day selfinterests and cares of people and states prevent the success of that important for everybody aim. And this proverb is related not only to scientific creature, but also to relations among people. As it is said: "One must not only to know much, but also to be able much." Also we must note that all our messages to mention organizations and congresses on ethical problems remained without any answers and following dialogs. But due to great Plato those who do not want dialogs will not reach any perspectives. In comments on Hegel's philosophy in his philosophical note-books V.Lenin often abuses it. And only with that saying he agreed somehow and said, "It is worth of respect the virtue of a peasant and a shepherd, however the right of the World Spirit is above all private rights." It is well known how that right was used by the leader of the world proletariat. In our everyday life, including in science, conscious or non-conscious, many try to represent that right, and there is nothing bad in it. But it is important how one must to understand it, as the right of selfless and devoted serving to truth and to the science or try to treat everybody who can be treated.

Let's state now briefly the main content of the basic ethical principle offered by us in (Bagdoev, Manukyan, 1999 ).

We recognize Kant as the greatest authority on ethics. Before his highest Reason, his starry sky and moral duty we stupefied in admiration. Intellect is the most highest. Therefore Ethics should follow the logics. But the Life goes forward, and 
together with it philosophy does. Now Kant's Reason and Hegel's Idea are withstood the Will, as a certain Space effort. Life of the space is a sea of energy from which acts of Will are allocated. These acts shaped the active beginning, generation of a Life and Being. Schopenhauer in his book 'The World as Will and Presentation' was the first who introduced that will as the concept 'Will to Life'. F.Nitshe introduced cosmic 'Will to Authority'. Bergson interpreted Will as a Vital Burst. We postulate together with Kant, that the maximum display of transcendental in personality is moral law in it, not intellect but moral duty as display of transcendentalism. Therefore at defining the formulating of the beginning of Life we start from ethical. As a forming beginning that drives the matter to the highest condition, we consider neither Bergson's Vital Burst, nor Schopenhauer's will to Life and F.Nitshe's will to Power but introduced by us moral rank-Will to Freedom. The Will to Power conducts to nonsenses, to chaos and falsity in the Life. As it is specified in (Daniel, 1990), it can be accepted only as Power above oneself in overcoming the weaknesses. The Will to Freedom conducts to progress, to becoming and development of Life that is constant movement to freedom. The Will to Freedom expresses Kant's categorical imperative. In an empire of freedom Kant searched the realization of high morals. Hegel made the concept of Freedom terrestrial defining it as true necessity. Communists wished to build a society of freedom in the world and to carry out in it their ideals. The developed of mankind, if to take it in aggregate of the person and the nature, is a movement to a society more free. As we clarified later the terminology of 'Will to Freedom' first was introduces by Jean Pole Sartre in his paper "Existentialism and Humanism". We offered an ethical principle that allows to estimate morality of an act and to stimulate the actions. It is formulated so. The act is moral that conducts to the maximal prize of total freedom for creativity. Total freedom is understood as the sum of increments of freedom of all persons concerning an act, thus, probably, the person making act loses, a little in freedom, but other persons participating in a situation, are released so that freedom totally wins. Not getting into details substations of necessity of a such principle, described above we dare to hope that it is actual and, at least on its experience, we constantly check its correctness and utility in attitudes towards people and first of all towards himself. In the sense of fidelity of the last statement we shall say that those succeeding personalities, who prefer the vital the vital blessings and momentary benefits to authentic creativity, are always known. By the way in (Otto, 1910) to his occasion is written 'The knowledge of the world is conducted only through suffering.' There are lots of examples that can confirm this idea. We'll bring the most vivid one-about the most gifted and the greatest Soviet mathematician and mechanic M.Keldish. His father, who wished him, of course, only good, had said, 'I thought that from him will turn out Anri Puancare, but it turned out to be only the President of the Academy of Sciences of the USSR'. So to that it is necessary to think of freedom for creativity not only for oneself, but for the surrounding, that usually almost nobody does. Well bring another witty example. It is known that T.Petrosyan differs from other chess players by making complicated combinations and, simply thought not only for himself but also for his contender. This is inherent, certainly, to all chess players but that brightly pronounced feature took away from him much more than from others, but invariably conducted him to success. You can check up on your own experience, whether it is concerned with the attitude between people, mainly between scientists, when somebody aspires to achieve success and only freedom for creativity due to another's, except for momentary, doubtful success and victory, finally wins nothing. Concerning such 'scientific' disputes and corresponding 'victories' does not suit the known saying, 'In disputes is born the truth', but it does V.Hugo's saying 'From two arguing is guilty only the one who is 
cleverer'. On the same theme there is winged, though too severe, saying of N.Winner, the best mathematician of the XX century, the founder of the theory of games,' the mankind is divided into two categories: fools and rascals. The first ones do not use all means in vital struggle and, certainly, lose, the second use all means and win, i.e. gain the victory. We wouldn't like someone relate us to the second category. As we have found out, very close to the questions of the article, already more than ten years, on a large scale the Russian Humanitarian Society is engaged. In one of its journals (Kruglov, 2006) there was the interview of the academician of the Russian Academy of Sciences V.Ginzburg propagandizing the necessity of secular or civil humanism. In the same number there was an article of the assistant to the editor-in-chief A.Kruglov, where it was said, 'Humanists approve the priority of universal values before any state national, class religious, ets., not denying the right of these private values of existence. This platform will constrain nobody, who only does not want to oppress others'. In the same number (Kruglov, 2006) we can find the following saying of the academician G.I.Abelev, 'Today the struggle for reason, humanism and common sense can be conducted only contrary to any common sense'. These and other aspirations of humanists of Russia and all world are according to our aspirations of creation of the general for all ethics creative 'super empirical personality', operating according to the cultural, values that are created by the best representatives of the mankind.

It is necessary to note thoroughgoing struggle of humanists with not less thoroughgoing Orthodox Church in their aspiration to represent ideology and cultural wealth of the modern personality. In this plan our positions are closer the aforesaid positions, ideological tolerance and even synthesis of all ideologies and it doesn't matter whether they are expressed by separate great thinkers or various religious faiths when it is a question about creating an image strong in sense of creative in all personalities about what it was in details spoken above.

After writing the main article we have got acquainted with philosophy of the personality developed by the remarkable follower and continuer of ideas of great Plato the great Armenian philosopher of the $\mathrm{V}$ century David the Invincible. He wrote quoting his teacher Plato: 'Philosopher is not one who knows much and not one who speaks much, but one who conducts innocent and pure way of life. 'David the Invincible divided philosophy into 2 parts: theoretical philosophy or according Kant 'criticism of the pure reason' and practical philosophy, according Kant 'criticism of the practical reason' and the same as also Kant preferred the second, representing nothing but ethics or the theory of morals for the personality. Here it is approved once again that all great thinkers speaking about the construction of the theory of the moral human personality, express the same ideas. In full accord with F.Nitshe's ideas about necessity to overcome the weaknesses there is a statement of David the Invincible that proposes of practical philosophy - with assistance of reason is to decorate morals and to subordinate to it the emotions. In full conformity with Hegel's philosophy is David's theory about experiment, that makes the Supreme Essence or the World Idea having created the nature and the mankind, and this beings comes to the self-actualization and to the movement to the basic purpose of the development of the nature and mankind: to the creation of an image of ideal godlike personality i.e. on our terminology 'super empirical' personality or the subject of creativity in everything, and on Nitsh's terminology 'super personality'. The practical philosophy according David is justice that conducts a person and a human society to the perfection. To those Plato's ideas David added a little with giving due to the knowledge and propagation of the truth, but on the first place puts the kindness. This kind of category in moral theories one couldn't find anywhere, including in antique, and in German philosophy. Besides, he as- 
serted, that for the kindness one may sometimes wander from the real truth. David's statement sounded more real to our construction of the ideals of Armenians what we consider suitable and for all mankind. It is a question of the spiritual heritage that has been created by the best representatives of all nations and people, which is followed by everyone in the present and in the future, according to their tastes and bents to use for their selfimprovement. Hardly there will be such 'strong' personality who without essential damage for himself will risk in a pointed manner to neglect that simple unpretentious recommendations. Let's note that in David's theory about the primary meaning of the category of the kindness on the first place is humanism.

In paper (Drize, 2006) it is spoken about ethics of science, about that even great scientists of world, as Newton, Kepler, Galilei, Mendel, in any case broke it very much (all it by mentioned phrase of Larosh Fuco). These facts in his interview brought assistant director of Institute of physiology correspondent- member A.V.Yurevich, specialist on ethics of sciences. He quoted the famous sociologist Robert Merton, who formulated main ethical norms of scientific activity:

1. Objectivity, i.e. only aspiration to truth 2 . Impartiality. 3. Communism, i.e. wide association propagation of knowledge, the result of scientist belongs to all. 4. By Rene Decart "Subject of all to doubt". And then: "The scientists, probably, more than anyone, are subjective; aspire to glory by all

\section{REFERENCES}

Bagdoev, Manukyan. (Bagdoev A.G., Manukyan E.L. About one optimal ethical principle //Information technologies and 1999). About one optimal ethical principle. Applied and mathematical aspects of the natural sciences. possible means and so on." These conclusions, declared by leading psychologists are in accordance with main propositions of our paper, i.e. with conclusion that mankind, more precisely its leading representatives, yet must prove its impartialities and competence in precision of creative results of personalities. By recapitulating of all these, we can assume, with more resoluteness, that for greatest effectiveness of the science it must be directed only by Brahmins. The ideas of this paper are in accordance with ideas of humanism, formulated in (Kruglov, 2006) where there are not references on Jean Pol Sartor paper "Existentialism and Humanism", and where there are speaking about priority of common to all mankind values.

Of course, one must completely agree with this appeal to allow enter into high level information society only of the high level personalities, who not only know much, but also to be able much. Indeed all known to us men during their interrelations show in this sense that although they know much, but are able nothing. But by comparison with modern science theories (Sedov, 1982) one must accept, that unfortunately, as in genetics high level of vitals form with low entropy must be supplemented by low level of mutations, without which cannot be the development of species. So we are obliged to accept that the low order of present interrelations among people one can adopt, also in future, but by taking into account and pointing out their low level and necessity of their Submission to aim and demands of high level laws.

Galevi Daniel. (1990). Life of Fridrikh Nitshe. Maoscow: Sov.Writer.

Sedov E. (1982). One formula and all world. Moscow.

Guayta Dyovanni. Life of man, m. o. (1990). Life of man, meteeng of sky and earth. Moscow.

Kruglov A.G. Sacred war with the Humanism // "Za Zdravi smisl." Journal of skeptics, o. a. 
(2006). Za Zdravi smisl. Journal of skeptics, optimists and humanists, Moscow.

Otto, V. (1910). Sex and character. Moscow.

Ajvasyan S. (2006). The Armenia and Biblean stories.

Yerevan.
Drize Yu. (2006). Not to be, but to be considered. POISK. Weekly magazine of scientific association, $N 16$. 